CHILDHOOD AND ADOLESCENCE IN ANGLO-SAXON LITERARY CULTURE 
This page intentionally left blank 


\section{Childhood and Adolescence in Anglo-Saxon Literary Culture}

EDITED BY SUSAN IRVINE AND WINFRIED RUDOLF

UNIVERSITY OF TORONTO PRESS Toronto Buffalo London 
(C) University of Toronto Press 2018

Toronto Buffalo London

www.utorontopress.com

Printed in the U.S.A.

ISBN 978-1-4875-0202-7

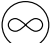

Printed on acid-free, $100 \%$ post-consumer recycled paper with vegetable-based inks.

\section{Library and Archives Canada Cataloguing in Publication}

Childhood and adolescence in Anglo-Saxon literary culture / Susan Irvine, Winfried Rudolf, editors.

(Toronto Anglo-Saxon series; 28)

Includes bibliographical references and index.

ISBN 978-1-4875-0202-7 (hardcover)

1. English literature - Old English, ca. 450-1100 - History and criticism.

2. Children in literature. 3. Adolescence in literature. 4. Families in literature. I. Irvine, Susan (Susan Elizabeth), editor II. Rudolf, Winfried, editor III. Series: Toronto Anglo-Saxon series ; 28

PR173.C45 2018 829'.093523 C2017-904923-2

University of Toronto Press gratefully acknowledges the financial assistance of the Centre for Medieval Studies, University of Toronto, the English Department at University College London, and the University of Göttingen in the publication of this book.

University of Toronto Press acknowledges the financial assistance to its publishing program of the Canada Council for the Arts and the Ontario Arts Council, an agency of the Government of Ontario.

\section{Conseil des Arts} du Canada 